\title{
PEREgRINA DA LOUCURA: IMIGRAÇÃO E RESISTÊNCIA NO CONTO "SÓ VIM TELEFONAR", DE GABRIEL GARCÍA MÁRQUEZ
}

\author{
PILGRIM OF MADNESS: IMMIGRATION AND \\ RESISTANCE IN THE SHORT STORY "I ONLY CAME TO \\ USE THE PHONE”, BY GABRIEL GARCÍA MÁRQUEZ
}

Andressa Kelly Lima Moura*
Carolina de Aquino Gomes
Maria Escolástica de Moura Santos

Resumo: O presente trabalho parte da análise literária do conto "Só vim telefonar", que compõe a obra Doze contos peregrinos, de Gabriel García Márquez. Por meio do conto, analisamos temas como latino-americanidade e peregrinação, e de que modo o entrelaçamento desses fatores impele a personagem principal, María de la Luz Cervantes, a vivenciar infortúnios e desventuras próprias do insólito que compõe o Realismo Maravilhoso, gênero literário que dá forma ao conteúdo da narrativa. Para tanto, empreendemos uma análise do contexto histórico da América Latina no tocante aos temas da imigração, exílio, ditaduras etc., fenômenos recorrentes na história do continente, e que dialogam diretamente com o conto analisado, permitindo-nos elucidar o porquê de a imigração ser uma problemática na América Latina e qual imagem do continente esta nos devolve.

Palavras-chave: Imigração. América Latina. Resistência.

ABSTRACT: The present work is a literary analysis of the short story "I only came to use the phone", which is part of the book named Strange Pilgrims written by Gabriel García Márquez. Through it, we analyze the Latin Americanity and pilgrimage themes, as well as how the intertwining of these factors impels María de la Luz Cervantes, the main character, to experience sorrows and misfortunes typical of the unusual which makes up the magical realism which is the literary genre that shapes the narrative. To this

\footnotetext{
"Graduando do curso de Letras Português pela Universidade Federal do Piauí. E-mail: andressaklmo11@gmail.com.

"*t Professora Adjunta da Universidade Federal do Piauí (UFPI), doutora em Letras, área de concentração Literatura Comparada (UFC). E-mail: carolina@ufpi.edu.br.

*at" Doutora em Educação (UFC); Profa. Adjunta da Universidade Federal do Piauí, Departamento de Fundamentos da Educação (DEFE); Líder do Núcleo de Estudos e Pesquisas em Educação e Emancipação Humana - NESPEM. E-mail: escol.santos@hotmail.com.
} 
end, we undertake an analysis of the historical context of Latin America regarding the themes of immigration, exile, dictatorships etc., recurrent phenomena in the history of the continent and which dialogue directly with the analyzed short story, this overview allows us to clarify both why immigration is a problem in Latin America and what the giving image of the continent is.

KEYwoRDs: Immigration. Latin America. Resistance.

\section{INTRODUÇÃo}

A presente análise construída nestas páginas tem por objeto o conto "Só vim telefonar", da obra Doze contos peregrinos, de Gabriel García Márquez. O conto narra a infausta trajetória de María de la Luz Cervantes, uma mexicana de 27 anos, ex-atriz e assistente de um prestidigitador de salão, conhecido como Mago Saturno, com quem também é casada. A moça estava viajando pelo deserto em um carro alugado quando este sofre uma pane. O que lhe resta é ficar por horas pedindo socorro para os carros, em vão. Até que um ônibus lhe oferece carona e ela aceita, dizendo que quer apenas ir a um lugar onde possa dar um telefonema para avisar ao marido sobre o ocorrido e que irá se atrasar. Assim inicia-se a penosa desventura de María rumo a um manicômio que a fará sucumbir a várias situações de violência e perda de sua autonomia.

Partindo de um aspecto mais geral, a escolha dessa obra baseia-se no interesse de apreender a construção ficcional dos sujeitos latino-americanos e as relações que os atravessam ficcionalmente, mas que possuem verossimilhança, implicando em um reflexo do real que permite uma compreensão de aspectos sociais, políticos, culturais e históricos da América Latina, e, portanto, dos sujeitos latino-americanos. O próprio nome da obra traz em seu título uma realidade que historicamente permeia a América Latina, a saber, a peregrinação. Isso remete, também, à ideia de imigração e exílio, um fenômeno demasiado recorrente no continente. Aqui se pretende abordá-lo, especificamente, recortando-o a partir dos anos em que os contos são escritos, entre o final dos anos 1970 e início dos anos 1980, quando uma onda de regimes ditatoriais, ou suas recentes marcas, imperaram sobre os países do continente, $o$ que é determinante para as migrações e exílios.

Ademais, buscamos levantar alguns aspectos estruturais desse fenômeno, para isso, foi imprescindível a abordagem da relação existente entre os continentes Europa e América Latina. Em Doze contos peregrinos, como deixa claro o autor no prólogo, o destino dos peregrinos é sempre algum país da Europa, representada aqui como lugar de infortúnios. Ambos são tomados de forma historicamente oposta nas relações colonizador/colonizado, centro/ periferia. Assim, para esses fins, é muito importante apreender essa significação para perceber como ela está representada ficcionalmente e como determina, de certa maneira, o destino da personagem, a intenção da autoria, e mesmo os encaminhamentos da presente análise. 
Doze contos peregrinos (1992), do escritor Gabriel García Márquez, é um compilado de doze contos que narram histórias de latino-americanos que, por motivos diversos, estão na Europa, seja morando ou viajando. Segundo o próprio autor, sua intenção era "escrever sobre as coisas estranhas que acontecem aos latino-americanos na Europa" (MÁRQUEZ, 2014, p. 10). Assim, a partir da obra, é possível refletir sobre várias questões históricas, políticas, culturais, sociais e econômicas inerentes à América Latina. Nesse sentido, tanto as narrativas de Gabriel García Márquez quanto este trabalho buscam elucidar um dos grandes dilemas do sujeito latino-americano, a saber, sua compreensão de si mesmo e o lugar da latino-americanidade. Esse movimento não só remete à ideia de peregrinação contida no título da obra como também é fruto dela.

Um aspecto relevante e comum a todos os contos, que também procuramos explorar, trata-se do cenário, do espaço em que se dá o desdobramento dessas situações estranhas, o continente europeu. Compreender esse paralelo e essa construção é uma das motivações da pesquisa, assim como compreender a ideia de peregrinação/imigração/exílio, que é imanente ao livro, presente não só nas narrativas, mas também na intencionalidade e no contexto do autor. Além disso, uma visão panorâmica da produção literária na América Latina nos permite ver que esse é um fenômeno imbricado na literatura do continente e no seu contexto de produção.

Correspondendo ao discurso e à sua significação, a obra mais reconhecida de García Márquez, Cem anos de solidão (2017), traz em si o principal tema de sua produção: a solidão. Esse fato nos leva a compreender que a solidão é um dos principais elementos que compõem o drama humano universal, o qual o autor particulariza, de forma aguda, no drama do latino-americano. Dessa forma, partimos do entendimento de que a solidão também é uma marca em todos os contos de Doze contos peregrinos, logo, esse aspecto permeia todo o conto aqui analisado. Assim, se a solidão é uma realidade do sujeito latino-americano, ela assume um desdobramento maior quando esse sujeito peregrina e se depara com inúmeras adversidades, inexplicáveis, levadas a cabo pela força do insólito presente em uma narrativa realista-maravilhosa.

A análise das narrativas junto ao estudo do Realismo maravilhoso e do Insólito ficcional foi também de grande importância para explanar como esses modos de construção narrativa abarcam esses e outros referentes da América Latina, mas que também transcendem suas particularidades. Entender os vieses do Realismo Maravilhoso é relevante porque, ao surgimento e ao modo como esse gênero se desenvolveu, estão intrínsecos aspectos que auxiliam na compreensão da América Latina e, portanto, da latino-americanidade. O fato de que esse é um gênero próprio do continente para apreender o "conjunto de objetos e eventos reais que singularizam a América no contexto ocidental" (CHIAMPI, 1980, p. 32) demonstra isso. Já a explanação do Insólito voltou-se mais especificamente para a análise da trajetória da personagem principal em "Só vim telefonar", elucidando a irrupção do improvável a partir de acontecimentos triviais. 
Percorrido esse caminho, dedicamo-nos a uma análise mais concentrada do conto junto à latino-americanidade e peregrinação, procurando investigar por que migrações são uma constante na América Latina; por que a referida personagem migrou; e, principalmente, por que esse conjunto de fatores a conduz por caminhos insólitos, árduos e violentos. As respostas alcançadas nesta análise nos permitem entender o motivo que faz com que os latino-americanos sejam ou possam ser, ainda hoje, representados como típicos personagens do insólito, das barbáries e infortúnios que frequentemente os acompanham, seja na sua terra natal ou no vertiginoso arquipélago das migrações, do qual nos fala Canclini (2008). A obra nos permite elucidar como a resistência está presente e é refletida como uma característica da América Latina, que respondeu com intensa obstinação aos momentos e episódios mais violentos de sua história.

\section{O REALISMO MARAVILHOSO E O INSÓLITO FICCIONAL: ABORDAGENS POSSÍVEIS}

O presente tópico parte da teorização sobre duas abordagens diferentes em relação à literatura que subverte o realismo tradicional, a saber, o Realismo Maravilhoso e o Insólito. Essa escolha deu-se a partir de um impasse sobre qual hipótese de leitura poderia contemplar de forma mais completa o conto "Só vim telefonar". Entendendo que, muitas vezes, apenas uma abordagem não dá conta de uma narrativa inserida em um livro tão plural, optamos pelas duas vertentes, para fins diferentes. Ambas certamente se complementam, abarcando as várias possibilidades de análise que o conto possui.

Esse impasse diz respeito ao seguinte fato: a maior parte dos contos, não só da obra Doze contos peregrinos, como da produção de García Márquez como um todo, enquadram-se no Realismo Maravilhoso, e este possui uma relação direta com a realidade latino-americana. Antes de explanar como o Realismo Maravilhoso opera em uma narrativa, adiantamos que um de seus pressupostos é a coexistência não contraditória entre o real e aquilo que subverte as leis do real, ou seja, o irreal, o sobrenatural. Acontece que o conto aqui analisado não possui essa característica. Possui, por sua vez, uma série de acontecimentos imprevisíveis potencializados com infortúnios.

Assim, a esses infortúnios potencializados que conduzem a narrativa, trataremos como o Insólito. Isso não implica dispensar o Realismo Maravilhoso, considerando que este emerge diretamente do contexto latino-americano, dando assentamento referencial para a narrativa, o que justifica esta escolha. Considera-se também que ambas as abordagens não se excluem, ao contrário, o Realismo Maravilhoso opera por meio da dialética existente entre o real e o insólito, dessa forma, este engloba aquele.

Flavio García (2019) aponta que o Insólito ficcional é perpassado por uma série de conceitos difusos e confusos. Em sua perspectiva teórica, o autor o trata como um macro/arquigênero ou termo conceito que engloba uma categoria da ficção, assim, desvia-se da questão 
temática e de efeito e o concebe como procedimento de construção narrativa. Essa construção envolve a composição de tempo, espaço, personagens, da verossimilhança, que em algum ou vários momentos da narrativa são transformados pela irrupção do insólito, subvertendo também a lógica, o racional, o verossímil, em menor ou maior grau.

Assim como o costumeiro, a imprevisibilidade faz parte da realidade, a maioria dos imprevistos cotidianos não são compreendidos como algo insólito, fora das possibilidades do acaso. É a partir da subversão desse elemento que o autor realiza o procedimento de construção narrativa do insólito no conto "Só vim telefonar”. Gabriel García Márquez narra um imprevisto acontecido com a personagem: seu carro sofre uma pane. A irrupção do insólito acontece quando o único veículo que oferece carona à moça é um ônibus que levava mulheres consideradas loucas para um sanatório distante, violento, macabro e sem contato com o mundo externo. A partir do momento em que María entra no ônibus, não há nada que a diferencie das outras mulheres, e sua necessidade de dar um telefonema é vista como a obsessão que atesta sua loucura.

O insólito dessa narrativa não possui o maravilhoso ou o fantástico, os acontecimentos são triviais. Ele atua no improvável, ou seja, quais as chances reais de uma pessoa pegar carona em um ônibus que está indo para um sanatório e isso fazer com que ela seja aprisionada nesse lugar por tempo indeterminado? E de que a simples necessidade de dar um telefonema possa ser vista como um traço de loucura? Por isso, o imprevisível é potencializado com um infortúnio extremo, decretando a clausura e a solidão de María. Apesar de não possuir o sobrenatural, ou exatamente por isso, o conto causa tamanha perplexidade e inquietação, pois demonstra que o insólito faz parte do real, podendo ser uma extensão deste e do que o humano pode experimentar no mundo.

A importância do Realismo Maravilhoso para a presente análise se dá pelo fato de que este se constitui como um gênero literário que busca aquilo que é imanente à realidade latino-americana. Ao surgimento e ao modo como esse gênero se desenvolve estão intrínsecos aspectos que auxiliam na compreensão da América Latina e da latino-americanidade.

Outro fator relevante é o método adotado por Chiampi (1980) na teorização do Realismo Maravilhoso. Este, como discurso literário, é amparado por uma teoria própria de construção e análise literária que, entre outros aspectos, produz e mantém relações semânticas. Assim, a compreensão das relações semânticas do Realismo Maravilhoso é muito importante para apreender o discurso sobre a América e suas contradições, maravilhas, antinomias etc. Segundo Chiampi (1980), o referente extralinguístico ocupa a base da relação no diálogo com o signo narrativo. Nesse sentido, a autora propõe a aplicação do método translinguístico, que

[...] consiste no estudo do signo na sua totalidade concreta, sem fazer abstração [...] das feições vivas do signo, da sua envoltura contextual (cultural, social). Conforme definiu Bakhtin, o discurso poético vai além 
do sistema da língua e não pode ser abordado fora de uma troca dialógica (CHIAMPI, 1980, p. 90).

Essa proposta nos orienta a buscar a relação dialógica entre o texto analisado e o contexto que lhe dá assentamento no real. Para isso, é preciso considerar o discurso presente na América Latina que coexiste com o discurso do Realismo Maravilhoso, isso remete ao referente extralinguístico da narrativa que enseja um discurso ideológico sobre a América. Assim, para apreender toda a riqueza do conto "Só vim telefonar", consideramos necessário apontar os referentes extralinguísticos e as simbologias presentes na narrativa que a tornam ainda mais complexa e relevante.

\section{"Só VIM TELEFONAR": LATINO-AMERICANIDADE E PEREGRINAÇÃo}

Como dito anteriormente, este artigo pretende propor um debate sobre a América Latina através da análise de uma literatura que busca alcançar o mesmo objetivo. Por que então a escolha de uma obra que espacialmente descreve outro continente, outros países, alheios à América? A resposta imediata seria a de que a obra narra a história de personagens que são latino-americanos. A resposta mediata e muito relevante é a de que ela reflete uma imagem da América Latina que "não está completa na América Latina. Sua imagem é devolvida por espelhos dispersos no arquipélago das migrações” (CANCLINI, 2008, p. 25).

Esse arquipélago das migrações sobre o qual nos fala Canclini (2008) é revelador de grandes questões e dilemas não só continentais, mas mundiais. Nesses espelhos dispersos estão contidas tensões políticas e econômicas, como a constante desconfiança na capacidade de administração do Estado, o comércio fluído, a privatização de bens públicos, a devastação dos direitos dos trabalhadores, a violação dos direitos humanos, todos relativizados no horizonte do capitalismo mundializado. Soma-se a isso a fragilidade das democracias latino-americanas, que historicamente mostraram-se bastante vulneráveis a golpes e retaliações.

Esses fatores são produzidos e reproduzidos no seio da globalização. Sobre esta, Mészáros (2011, p. 111) coloca que é uma tendência que emana da natureza sempre expansiva do capital desde o seu início, e que, a despeito de sua idealização nos nossos dias, "na realidade significa: o desenvolvimento necessário de um sistema internacional de dominação e subordinação". Tal sistema opera no macro e no microcosmo de todas as esferas, comprometendo "desde as mais íntimas relações pessoais aos mais complexos processos de tomada de decisão [...], sempre a favor dos fortes e contra os fracos” (MÉSZÁROS, 2011, p. 96).

Acreditamos que esse é o cerne do arquipélago das migrações que dispersa a América Latina no mundo, e que produz, no imigrante e no emigrado, o latente sentimento expresso na frase "Voltar não tem sentido, tampouco viver ali", ${ }^{1}$ cantada pelo uruguaio Jaime Roos na

${ }^{1}$ Volver no tiene sentido, tampoco vivir allí (tradução nossa). 
música Los Olímpicos, de 1981. Também Doze contos peregrinos, em cada um dos seus contos, reflete ficcionalmente esse drama humano sob diferentes perspectivas, mas sempre partindo da mesma realidade concreta que, em sua riqueza de conteúdos e formas, produz esse drama, realizando aquilo que é próprio do reflexo estético. Isso, segundo Lukács (2018), implica colocar-se diante de questões socialmente postas na totalidade da realidade e de problemas condicionados pelas relações de produção.

Tendo em vista esse dilema do imigrante cantando por Jaime Ross, Reis (1988) aponta que o lugar da latino-americanidade, o fato de termos incorporado e unido características exógenas e autóctones, e a própria literatura latino-americana demonstram isso, tudo isso produz para a América Latina um espaço pautado na ideia de entrelugar, de um lugar clandestino, onde operam forças opostas. É nessa direção que atua a produção ficcional latino-americana e Realista Maravilhosa. Longe de tentar definir “o que é a América Latina”, esta realiza uma tarefa mais importante: dar vez e voz à América Latina, aos problemas cotidianos e históricos vivenciados pelos latino-americanos. Assim, essa literatura nos torna sujeitos e não mais objetos de nossa história, pelo menos no campo cultural e intelectual-artístico.

Doze contos peregrinos apreende, por meio dos motivos que levam cada personagem a imigrar, obstáculos comuns: todos são latino-americanos que, de alguma forma, sofrem infortúnios, eles personificam, com isso, a resistência que os faz persistir. Enquanto em alguns contos os personagens migram por motivos políticos, outros o fazem por questões religiosas ou a trabalho, mas em "Só vim telefonar" a razão não é tão definida. María é uma mulher com um espírito bastante livre no seu tempo, que amava e desamava quando queria, assim como deixava e retomava um relacionamento imprevisivelmente. No dia de seu casamento, festejou, mesmo tendo sido abandonada no altar, e retornou para Mago Saturno, seu ex-namorado e agora marido.

Por amor a ele, renunciou o seu sonho de ser atriz e o seguiu como sua assistente de palco. Anos antes, María tinha sido uma reconhecida atriz no México, e abdicou disso para mudar-se com o marido para Barcelona, após retornarem de um congresso de magos. Mesmo tendo passado de atriz a assistente de palco, pois como estrangeira dificilmente María conseguiria seguir a mesma carreira, ela estava feliz. Até o insólito continente europeu desfazer sua liberdade, enclausurando-a em um manicômio, implicitamente pelo seu lugar de peregrina latino-americana, o que nos encaminha a refletir que imagem da América Latina essa narrativa devolve através dos espelhos dispersos no arquipélago das migrações.

\section{MARÍA ATRAVÉS DOS ESPELHOS: OS CONFLITOS DA PERSONAGEM NO ARQUIPÉLAGO DAS MIGRAÇÕES}

As narrativas de Doze contos peregrinos devolvem, de fato, uma imagem da América Latina, mas não só. Há também o reflexo do lugar para onde esses latino-americanos migraram 
ou por onde peregrinaram. Nesse caso, é preciso pensar também que imagem da Europa nos é devolvida através das narrativas e das vivências das personagens. Portanto, ao mesmo tempo que temos uma imagem da América Latina e uma imagem da Europa, temos a síntese entre ambos os continentes, ou seja, como um se relaciona com o outro, e vice-versa, em cada situação específica. Por meio desse movimento, pretendemos elucidar os conflitos vividos por María no continente europeu.

O insólito atua na narrativa junto à vulnerabilidade da peregrinação e conduz María de la Luz Cervantes, uma mexicana de 27 anos, a entrar em um ônibus preenchido por mulheres que seriam recém-chegadas a um sanatório. O desespero para avisar ao marido pelo telefone que não chegaria a tempo em casa, e a ingenuidade de acreditar que nada de grave poderia lhe acontecer em um continente em que o bem-estar e segurança social são aparentemente as principais premissas, fizeram com que María adentrasse o veículo sem ao menos se certificar para onde estava indo, desde que pudesse telefonar.

Assim que desceu do ônibus, no pátio de um edifício descrito como enorme e sombrio, usando a mesma manta comum a todas as outras mulheres, María passou a ser tratada como uma delas pelas guardas. Ao chegar ao saguão perguntando pelo telefone, "uma das guardas fez com que ela voltasse para a fila dando-lhe palmadinhas nas costas, enquanto dizia com modos muito suaves: - por aqui, gracinha, o telefone é por aqui” (MÁRQUEZ, 2014, p. 108). Mas na verdade ela foi conduzida ao dormitório das recém-chegadas, onde teve de permanecer mesmo sem ter seu nome na lista e sem número de identificação, afirmando que só foi telefonar.

Ao perceber que aquele edifício era, na realidade, um hospital para enfermas mentais, María se desesperou e saiu correndo do quarto, motivo pelo qual foi imobilizada no chão por Herculina, a guarda responsável pelos casos difíceis e que, por "acidente", já teria estrangulado duas reclusas.

O primeiro caso foi resolvido como sendo um acidente comprovado. O segundo foi menos claro, e Herculina foi advertida e admoestada de que na próxima vez seria investigada a fundo. A versão corrente era de que aquela ovelha desgarrada de uma família de sobrenomes grandes tinha uma turva carreira de acidentes duvidosos em vários manicômios da Espanha (MÁRQUEZ, 2014, p. 109).

Essa personagem é a personificação, na obra, de todo o descaso e violência institucional promovida pelo hospital e pelo Estado, sempre a favor dos fortes contra os mais vulneráveis, não só no aspecto físico, mas, principalmente, no aspecto social, sob custódia de um sobrenome grande. A admoestação dirigida à Herculina deixa implícito que haveria uma próxima vez, e, mesmo com seu histórico homicida, ela permanecia fazendo esse trabalho, o que permite questionar que parâmetros eram usados para afastar essas mulheres do seio social se pessoas como Herculina podiam permanecer. Com isso, é possível inferir que as mulheres 
reclusas, por algum motivo, eram indesejadas socialmente, por possuírem algum traço que gerava preconceito; já Herculina, mesmo sendo violenta e incontrolável, atua como aparelho da repressão e da clausura institucional, e esse é um ponto de contradição muito relevante para contextualizar os conflitos postos pela narrativa.

Acreditamos que três das principais personagens do conto em questão guardam algumas simbologias no próprio nome. Teceremos aqui algumas dessas relações com o papel das personagens na narrativa a partir de simbologias e arquétipos, começando por Herculina. É notória a associação do nome com a descrição da personagem, que faz referência ao mito de Hércules, pertencente à mitologia grega. O herói em questão incorpora o arquétipo da força desmedida e incontrolável, possuindo um trágico histórico de homicídio, que incluía seu mestre, ainda na juventude, e seus filhos com Megara. Por meio do próprio nome, Herculina guarda então uma relação arquetípica com a força descomunal, sevícia e brutalidade. Muito dessa força foi amplamente descarregada sobre María, que por suas ações subversivas e impetuosas era, de fato, considerada um caso difícil em uma estrutura repressiva.

O golpe desferido pela guarda dá início, assim, à amarga e cruel trajetória da personagem no sanatório, de onde se seguiu mais violência, entorpecimento, imobilizações, até perder os sentidos "num pântano de suas próprias misérias" (MÁRQUEZ, 2014, p. 110). Com isso, podemos dizer que María foi submetida a um duplo exílio, primeiro por não estar no seu país e sua família não saber de seu paradeiro, segundo por estar enclausurada em um manicômio. Portanto, é um exílio tanto no macrocosmo quanto no microcosmo, o que tornou tudo ainda mais penoso. Tal experiência remete à descrição de Cortázar sobre o exílio. Nas palavras desse autor, o exilado é

[...] alguém que se sabe despojado de tudo o que é seu, muitas vezes de uma família [...]. O exílio é a interrupção do contato de uma folhagem e de um enraizamento com o ar e com a terra conaturais, é como o brusco final de um amor, é como uma morte inconcebivelmente horrível porque é uma morte que se continua vivendo conscientemente [...] (CORTÁZAR, 2001, p. 149).

García Márquez, por meio desse conto, transpõe para a ficção o possível sentimento que atravessou grande parte dos escritores de sua geração nos anos de ditadura na América Latina. Mesmo que eles não fossem aprisionados dessa maneira, a sensação poderia ser muito próxima, segundo a descrição de Cortázar. Além disso, também remete às experiências de sequestro e tortura que sofreu a classe artística de vários países latino-americanos durante seus governos militares e ditatoriais. Por isso, a literatura do insólito liga-se ao verossímil sempre por um fio agudo de realidade, assim como o real liga-se ao improvável, ao incompreendido, sempre pelo agudo fio do insólito. 
Logo que acordou, após o primeiro episódio sério de violência, María foi levada à enfermaria para falar com o diretor do hospital, o único que María pensou compreendê-la. Este a ouviu e consolou, mas quando María finalmente pediu permissão para telefonar, ele adiou sua espera e desapareceu. À tarde, María recebeu o número de série que deveria estar em seu sutiã no dia em que chegara, em sua ficha estava escrito "um comentário superficial sobre o enigma de sua procedência e as dúvidas sobre sua identidade. Na margem ficou uma qualificação escrita pela mão do diretor: agitada" (MÁRQUEZ, 2014, p. 111, grifo do autor).

Embora o caminho que levou a personagem ao sanatório tenha sido um sortilégio do insólito, tudo o que ela viveu no claustro é narrado tendo como subsídio um realismo explícito e profundo, no sentido de desvelar a barbárie que pode viver um sujeito marginal e vulnerável em uma sociedade estruturada para excluí-lo de forma indiferente. Não fosse isso, o diretor do hospital buscaria averiguar se o que ouvira de María era verdade, e, principalmente, teria realizado um diagnóstico responsável que indicaria sua sanidade.

As descrições do sanatório apontam que aquele era um lugar hostil, lúgubre, medieval, cujo refeitório ostentava uma litografia do general Francisco Franco, os talheres eram acorrentados à mesa e a comida era escassa. María, apesar da relutância, foi se incorporando à dura vida. Um dia, por descuido, conseguiu estar sozinha com o telefone e ligou para o marido: “- Coelho, minha vida - suspirou”. As lágrimas a venceram. Do outro lado da linha houve um breve silêncio de espanto, e a voz ensandecida pelos ciúmes cuspiu a palavra: - Puta!" (MÁRQUEZ, 2014, p. 121).

A relação de María com o marido demonstra outra esfera conflituosa em sua vida, agora na instância privada, pois se trata de um homem conhecido em Barcelona pelos seus acessos de ciúme, por não ser razoável mesmo após dois anos de relação na qual María nunca havia se atrasado. "Naquela noite, num ataque frenético, María tirou da parede do refeitório a litografia do generalíssimo, arrojou-a com todas as suas forças contra o vitral do jardim, e desmoronou banhada em sangue” (MÁRQUEZ, 2014, p. 121).

Nesse ponto nos é devolvida uma imagem nevrálgica da América Latina das décadas em que o livro foi escrito. No prólogo da obra, publicado em 1992, o autor diz que esta foi escrita no curso dos últimos dezoito anos, e a primeira ideia lhe ocorreu no início da década de 1970. Entre os anos de 1962 e 1966 oito países latino-americanos sofreram golpes de Estado, cronologicamente: Argentina, Peru, Guatemala, Equador, República Dominicana, Honduras, Brasil, Bolívia e Argentina novamente; em 1973, Chile e Uruguai também sofreram intervenções militares. Os anos de redemocratização nos mesmos países datam de 1979, começando pelo Equador, a 1990, com o Chile.

Pode-se dizer que a obra peregrinou por todos esses anos de ditadura, golpes militares e grande instabilidade política, e que nesse aspecto a América Latina receberia o mesmo 
diagnóstico que María: agitada. A imagem do general Francisco Franco ${ }^{2}$ emerge no livro para fazer referência a todos os governos ditatoriais que assolavam o continente, exilando os insubordinados dentro ou fora do país e dando-lhes o mesmo tratamento que María recebeu após esse episódio de revolta:

[...] foi arrastada até o pavilhão das loucas perigosas, foi aniquilada com uma mangueira de água gelada, e injetaram terebintina em suas pernas. Impedida de caminhar por causa da inflamação provocada, María percebeu que não havia nada no mundo que não fosse capaz de fazer para escapar daquele inferno (MÁRQUEZ, 2014, p. 122).

Não é possível saber ao certo em que época histórica se passa a narrativa, mas, pela presença da litografia do referido ditador presidindo o refeitório do manicômio, e como a ditadura franquista durou quase quarenta anos, é provável que María esteja inserida nesse contexto. Nesse sentido, a obra faz referência à forte vigilância e repressão vigente nesse período. Como María foi atriz de novelas, pode-se dizer que remete também à ampla perseguição de artistas e ativistas que, em essência, eram contra o regime totalitário, "é por isso que são fuzilados escritores, professores, artistas, jornalistas", colocam Torre e Silva (2016, p. 16) sobre o regime.

Esses autores descrevem ainda que o franquismo "[...] foi um regime totalitário apoiado num fundamentalismo católico [...], estabelecido à base de reeducação, de censura e de repressão, com o fim de orientar, dirigir, dissuadir, restringir direitos, liberdades, e o pensamento próprio organizado dos cidadãos" (TORRE; SILVA, 2016, p. 18). Esse importante elemento histórico esclarece o esforço incongruente em manter María, mesmo saudável e sem nenhum histórico justificável, em um hospital para enfermas mentais, já que qualquer pessoa minimamente indesejada deveria ser censurada, arrancada do convívio social.

Assim, é bastante simbólico que María reduza a figura de opressão e belicosidade em uma atitude de resistência e insubordinação, seja torturada, mas, mesmo assim, mantenha-se resiliente em busca de sua liberdade. Novamente, há aqui uma aproximação entre a narrativa e a situação política da América Latina, dessa vez em relação aos movimentos insurgentes e indivíduos contrários aos regimes ditatoriais. O posicionamento político do autor faz-se ver tanto em suas obras quanto em sua vida social, a exemplo do discurso feito na ocasião do prêmio Nobel de literatura, em que García Márquez enfatiza a truculência desses regimes e os indivíduos mortos, expulsos ou torturados em nome disso.

A determinação da personagem desvela a culminância de outro conflito igualmente violento. Uma das guardas tentou subornar María em troca de favores sexuais, e chegou a abusá-la no dormitório. Na semana seguinte, María cedeu à insistência da guarda, e em troca

\footnotetext{
${ }^{2}$ O general Francisco Franco foi o ditador militar da Espanha após a guerra civil espanhola, e governou de 1939 a 1975 , quando veio a falecer. Seu governo, que recebeu o nome de franquismo, era baseado no autoritarismo e no catolicismo, as mesmas bases que estabeleciam o convívio e a ordem no sanatório narrado por Gabriel García Márquez.
} 
lhe pediu que levasse um recado a seu marido, avisando de seu paradeiro. Mago Saturno, ao chegar ao local, foi recebido pelo diretor do hospital, que falou que a situação de sua esposa era grave, pelos acessos de raiva e obsessão por telefones. Assim, o diagnóstico médico se sobrepõe a mais de dois anos de relacionamento, quando Saturno prefere acreditar no diretor do que no relato de María sobre o terror e a violência do cárcere, e resolve deixá-la ali.

Esse episódio causa uma grande cisão no comportamento de María, que se resigna ao claustro e recusa as visitas do marido. Durante esses meses, a personagem sofreu diversos tipos de violência, física, psicológica, institucional, sexual, mas, quando se viu desacreditada pela única pessoa que lhe fazia resistir, renunciou à sua liberdade. Por isso, não é possível afirmar se María de fato enlouqueceu, e, nesse caso, a responsabilidade seria completa do hospital, ou, se com sua sanidade, acostumou-se e suportou a vida no sanatório. Porém, nos inclinamos a crer que María conservou a lucidez de suas ideias e, por isso, conseguiu resistir.

Novamente, a simbologia do nome da personagem, como também seu percurso pela Espanha, desvelam algumas significações. María de la Luz Cervantes faz uma rica referência ao clássico personagem Dom Quixote de La Mancha, da obra El ingenioso hidalgo Don Quixote de La Mancha, ${ }^{3}$ e também ao seu escritor, o espanhol Miguel de Cervantes (1547-1616). Seu enredo amplamente conhecido narra a história de um homem que, após muito ler romances de cavalaria, incorpora a figura de um típico cavaleiro andante medieval que projeta na realidade percepções existentes apenas em seu próprio imaginário, o que abre uma questão a respeito da natureza da loucura e da lucidez, um dos temas centrais do conto em questão.

Por isso, sobre Dom Quixote, Gallian (2017) indaga se seu caso seria de loucura ou de excesso de razão, uma indagação pertinente também quando direcionada à María. No entanto, seu próprio nome, "de la Luz", aponta para a lucidez, que acreditamos ter sido conservada mesmo quando trilhou o mesmo caminho de Dom Quixote. Este inicia a segunda parte do romance retomando suas aventuras a caminho da cidade de Zaragoza, porém, antes de completar o trajeto, muda de ideia e vai a Barcelona (RUTHERFORD, 2012). Em seu percurso, María está exatamente voltando de Zaragoza rumo a Barcelona. Outra aproximação é posta pela peregrinação, que em ambos os casos é permeada pela possibilidade da loucura, essa combinação faz referência à ideia vertiginosa de se estar perdido.

Ainda sobre a simbologia dos nomes das personagens, que enriquece muito a narrativa, é pertinente a relação do nome do marido de María e suas ações no conto. Por ser lembrado pelo narrador apenas pelo nome de Mago Saturno, há a possibilidade de estabelecer uma relação simbólica entre este e o mito de Saturno, em seus aspectos negativos (para corresponder às

\footnotetext{
${ }^{3}$ A obra O engenhoso fidalgo Dom Quixote de La Mancha teve sua primeira parte publicada em 1605 e segunda parte publicada em 1615, sendo, para muitos críticos literários, a obra que inaugura o romance moderno. Séculos mais tarde, Gabriel García Márquez seria comparado a Cervantes por sua originalidade e maestria literária (MARTIN, 2019).
} 
ações da personagem), tanto na tradição romana quanto na astrologia ocidental clássica. ${ }^{4} \mathrm{Em}$ ambas, o mito de Saturno antecede as possibilidades de interpretação e aplicação.

Resumidamente, de acordo com a tradição mitológica romana, Saturno expulsou seu pai (Urano) da posição de deus, ao passo que, para evitar que também fosse destronado, comeu todos os seus filhos, menos Júpiter, que de fato tomou seu lugar. Roob (2014) expõe que, segundo a Ilíada, quando Júpiter vence Saturno, este passa a encarnar o aspecto destruidor do tempo, como Pai da Morte, e que "as influências do seu planeta eram consideradas responsáveis por todo tipo de pobreza e miséria” (ROOB, 2014, p. 171).

Segundo Romano (2013), a astrologia tradicional, valendo-se desse mito, coloca Saturno como aquele que simboliza "o inexorável, o poder limitante e retardatário sobre a vida” (ROMANO, 2013, p. 33). A autora enfatiza ainda que decepcionar e ser decepcionado são tendências da influência saturnina, e que dor, luto, mágoa, decepção são suas palavras-chave (na astrologia helenística). Sobre o aspecto negativo de Saturno, Chevalier (2016, p. 806) ressalta o significado do título "Grande Maléfico", que é atribuído a esse astro pela astrologia: "o nome de Grande Maléfico lhe é conferido a justo título, pois ele simboliza todo tipo de obstáculo, as paradas, a carência, o azar, a impotência, a paralisia”.

A partir dessas simbologias, acreditamos que a atribuição do nome "Mago Saturno" à personagem cumpre dois propósitos. O mais imediato é fazer referência à profissão de prestidigitador, ou seja, aquele que tem capacidade de iludir, manipular, fazer números de mágica. Roob (2014) afirma que Saturno, como deus, representa o patrono dos alquimistas, dos magos. O segundo propósito diz respeito às ações literalmente maléficas do marido sobre a vida de María, inclusive remetendo ao insólito que a permeia, sendo assim o leitmotiv de todo seu infortúnio, desde a busca pelo telefone, a submissão à violência sexual para conseguir contatá-lo a todo custo, até a permanência de María no sanatório por tempo indeterminado.

Disso, pode-se depreender a interpretação de que, assim como o deus Saturno queria evitar inescrupulosamente que seus filhos tomassem seu lugar no trono, devorando-os, Mago Saturno queria evitar que María, tendo um espírito livre e impetuoso, pudesse trocá-lo novamente ou simplesmente deixá-lo, por isso preferiu acreditar, de forma conveniente, na palavra do diretor. Porém, a inexorabilidade inerente à simbologia saturnina atesta a perda à medida do esforço para realizar o contrário.

Esse aspecto é aclarado por Chevalier (2016, p. 807) ao explicar que "o complexo saturnino é a reação da recusa de perder aquilo a que nos ligamos [...], as situações diversas de frustrações afetivas que levam a uma exasperação da avidez sob várias formas (bulimia, cupidez, ciúme, avareza, ambição, erudição)". Dessa forma, notadamente, a escolha de tal nome é intencionada e muito bem articulada para trazer à narrativa conotações simbólicas

\footnotetext{
${ }^{4} \mathrm{~A}$ astrologia ocidental clássica refere-se àquela composta pela tradição helênica, latina e persa, e corresponde aos estudos que antecedem a era de Cristo e que se estendem até o Renascimento (ROMANO, 2013).
} 
que a tornam ainda mais rica e complexa, ao trazerem simbologias e arquétipos da tradição literária grega, latina e romana.

Nesse contexto complexo e penoso, a experiência de María foi marcada por seguidos episódios que feriram sua integridade. Das definições postas por Marilena Chauí (1999), violência é tudo aquilo que age contra a natureza de um ser, de forma a desnaturá-lo. Assim, María é tolhida de si mesma, de sua natureza livre e saudável. A autora completa que violência é relativa à "brutalidade, sevícia e abuso físico e/ou psíquico contra alguém" (CHAUÍ, 1999, $\mathrm{s} / \mathrm{p}$ ). O conto "Só vim telefonar" reúne todas essas violências em uma mesma narrativa, sendo direcionadas a uma única personagem, para refletir a crueldade que se sucede ao silenciamento de um sujeito. Diante disso, é possível afirmar que as transgressões sofridas por María ocorrem, por um lado, para silenciá-la, e, por outro, porque ela foi silenciada.

O grande martírio da personagem configura-se pelo fato de em nenhum momento conseguir se comunicar, fazer-se entender. Todas as vezes que María tentou estabelecer um diálogo, sua comunicação se tornou tão remota quanto o telefone que ninguém nunca lhe cedeu, e a interlocução tão inalcançável quanto a possibilidade de dar um telefonema. Esse vácuo compõe um círculo vicioso quase inalterável, no qual a única saída é a resignação diante da circunstância que se impõe.

Essa é uma característica de várias personagens e narrativas de Gabriel García Márquez. Segundo Martin (2019), suas personagens quase sempre fracassam, e são raras as vezes em que conseguem se relacionar com os outros por mais de um instante. Esse círculo vicioso se reflete, além das ações, na estrutura geral das narrativas, que geralmente são circulares. $\mathrm{Na}$ impossibilidade de fazerem sua própria história,

[...] são o eco da história alheia, o último elo da corrente centro-periferia. A única explicação possível é que essas personagens vivem suas vidas em nome dos valores de outrem, ou dos sonhos de outrem. Daí a solidão e o distanciamento, temas recorrentes na história latino-americana: estão abandonados num continente vazio, num imenso vácuo cultural, a quilômetros de distância de seu verdadeiro lar (MARTIN, 2019, p. 387-388).

As obras de García Márquez são carregadas de certo pessimismo, porém, este não é vazio, mas vem acompanhado de uma interpretação de mundo feita precisamente a fim de desvelar a causa dessa solidão e violência, assim como para apresentar o caminho para que esse círculo se feche e outros sejam possíveis. Apesar de ficcionalmente suas personagens nunca se realizarem, as obras do autor têm o potencial de incidir no real de modo a causar nos seus leitores o incômodo e o ímpeto para transformar a realidade. Pessoalmente, o autor seguia esse mesmo ímpeto:

[...] ainda não é tarde demais para nos engajarmos na criação da utopia oposta. Uma nova e avassaladora utopia da vida, onde ninguém será 
capaz de decidir como os outros morrerão, onde o amor provará que a verdade e a felicidade serão possíveis, e onde as raças condenadas a cem anos de solidão terão, finalmente e para sempre, uma segunda oportunidade sobre a terra (GARCÍA MARQUEZ, 1982, s/p).

O conto ora analisado reflete diversos conflitos que dizem respeito à correlação de forças existentes entre dois continentes, e devolvem a cada um possíveis imagens. Entre a possibilidade de outras interpretações, temos a imagem de uma Europa indiferente e opressiva, em relação a uma América Latina heterônoma, desarticulada por forças internas e externas e, ainda, roubada de si. Apesar disso, há também, e deve haver, resistência e ímpeto para construir condições materiais que produzam outras possibilidades na América Latina e no mundo.

\section{Considerações finaIs}

Este artigo, pautado na análise literária do conto "Só vim telefonar", buscou elucidar em que medida o entrelaçamento dos fatores latino-americanidade e peregrinação concorreram para a trágica trajetória de María no continente europeu. Com isso, é possível compreender as forças coercitivas que atuam no continente latino-americano e que tornam essa narrativa verossímil, na medida que esta amplifica artisticamente um fenômeno tão real e constante na América Latina, a saber, a migração e seu extenso corolário.

Após esta análise, é possível afirmar que a presente narrativa estende ao extremo a condição da solidão, tema tão recorrente na literatura de Gabriel García Márquez. Aqui, a solidão e a sujeição à hostilidade do outro estão representadas de maneira tão implacável que nem mesmo o marido de María, sob a égide do amor, a redimiu da solidão do claustro, da condição de silenciamento, peregrinação e violência; ao contrário, somou forças com tal situação. Porém, toda essa violência não pôde roubar da personagem a única coisa que a fez suportar e subverter o claustro: seu intenso ímpeto de resistência, que acreditamos ser próprio de sua latino-americanidade.

Desse modo, conclui-se que o conto alcança e reflete, de forma aguda, o drama universal da migração, que muitas vezes se converte em uma peregrinação errante e frustrada diante das contradições que regem a sociedade capitalista. A narrativa nos põe como alternativa para tal hostilidade a ação de permanecermos acreditando na lucidez das próprias ideias, como fez María, resistindo até mesmo aos escombros de seu claustro. Diante disso, este artigo pretende reafirmar tal alternativa e reiterar, ainda, a possibilidade da construção da utopia oposta - de que falou Gabriel García Márquez - no devir histórico da humanidade, em uma realidade livre de hostilidades, exploração e solidão. 


\section{REFERÊNCIAS}

CANCLINI, Néstor García. Latino-americanos à procura de um lugar neste século. São Paulo: Iluminuras, 2008.

CHAUÍ, Marilena. Uma ideologia perversa: explicações para a violência impedem que a violência real se torne compreensível. Folha de São Paulo, São Paulo, 14. mar. 1999. Disponível em: https://www1.folha.uol.com.br/fsp/mais/fs14039904.htm. Acesso em: 14 abr. 2020.

CHEVALIER, Jean. Dicionário de símbolos: (mitos, sonhos, costumes, gestos formas, figuras, cores, números). 29. ed. Rio de Janeiro: José Olympio, 2016.

CHIAMPI, Irlemar. O realismo maravilhoso. São Paulo: Perspectiva, 1980.

CORTÁZAR, Julio. América Latina: exílio e literatura. In: SOSNOWSKI, Saúl (org.) Obra Crítica/3. Rio de Janeiro: Civilização Brasileira, 2001. 334p.

GALLIAN, Dante. 1 Vídeo (10 min). Don Quixote: loucura ou excesso de razão? Publicado pelo canal Cada do Saber, 2017. Disponível em: https://www.youtube.com/watch?v=UjbCiJmfVfo. Acesso em: 1 set. 2020.

GARCÍA MÁRQUEZ, Gabriel. Doze contos peregrinos. 25. ed. Rio de Janeiro: Editora Record, 2014. GARCÍA MÁRQUEZ, Gabriel. A solidão da América Latina. 1982. Disponível em: http:// thomasvconti.com.br/2014/discurso-de-gabriel-garcia-marquez-ao-receber-o-premio-nobelde-literatura/. Acesso em: 15 maio 2020.

GARCÍA, Flavio. "Insólito”. In: REIS, Carlos; ROAS, David; FURTADO, Filipe.

GARCÍA, Flavio; FRANÇA, Júlio (Editores). Dicionário Digital do Insólito Ficcional (e-DDIF). Rio de Janeiro: Dialogarts. Disponível em: http://www.insolitoficcional.uerj.br/i/insolito-ficcional/. Acesso em: 13 abr. 2020.

LUKÁCS, Geog. Introdução a uma estética Marxista: Sobre a Particularidade como Categoria Estética. São Paulo: Instituto Lukács, 2018.

MARTIN, Gerald. A narrativa latino-americana, c. 1920-c. 1990. In: BETHELL, Leslie (org.). História da América Latina. v. 8. São Paulo: Editora da Universidade de São Paulo, 2019.

REIS, Ricardo. O espaço da latino-americanidade. Crítica Literária Latino Americana, Lima, 1988, p. 25-37. Disponível em: https://www.jstor.org/stable/4530363?seq=1\#metadata_info_ tab_contents. Acesso em: 6 mar. 2020.

ROMANO, Clélia. Astrologia tradicional na prática. 1. ed. São Paulo: Edição de autora, 2013.

ROOB, Alexander. O museu hermético: alquimia e misticismo. 1. ed. São Paulo: Taschen, 2014. 
RUTHERFORD, John. Introdução. In: CERVANTES, Miguel. Dom Quixote. 1. ed. São Paulo: Penguin, 2012.

TORRE, Matías Rodríguez da; SILVA, Xosé Manuel Baamonde. A repressão franquista na língua galega. A desfeita de uma realidade linguística, cultural e nacional. Caracol, v. 11, 2016, p. 10-37. Disponível em: https://www.revistas.usp.br/caracol/article/view/118327. Acesso em: 3 jun. 2020.

Recebido para publicação em: 1 jul. 2021.

Aceito para publicação em: 29 nov. 2021. 